\title{
FISCAL DECENTRALIZATION POLICIES AND SUB-NATIONAL GOVERNMENT DEBT IN EVOLVING FEDERATIONS*
}

Teresa Garcia-Milà Department of Economics Universitat Pompeu Fabra

\author{
Timothy J. Goodspeed \\ Department of Economics \\ Hunter College
}

\author{
Therese J. McGuire \\ Institute of Government and Public Affairs \\ College of Urban Planning and Public Affairs \\ University of Illinois at Chicago
}

\author{
Draft: May 28, 2002 \\ Do Not Quote Without Permission \\ Comments Welcome
}

\begin{abstract}
As part of a process of democratization, many countries spanning Europe, Latin America, Africa, and Asia are reorganizing their governments by devolving fiscal responsibility and authority to newly empowered regional and local governments. Although decentralization in each country proceeds differently, a common element tends to be an initially heavy reliance on central government grants to fund regional spending. We develop a theoretical model of regional borrowing decisions in which the incentives for regional borrowing depend crucially on how the regions expect the federal system of finance to evolve. We examine the implications of the model using data on Spanish regions for the period 1984-1995 and find evidence that regions may be borrowing inefficiently in response to incentives imbedded in the Spanish system of fiscal decentralization.
\end{abstract}

*The authors are very grateful to the Tinker Foundation Inc. for financial support for this research. GarciaMilà gratefully acknowledges support from DGICYT, Ministerio de Educación y Ciencia, Spain. We received helpful comments from Alan Auerbach, Randy Filer, Michael Greenacre, Doug Holtz-Eakin, Ingmar Nyman, Rob Porter, Jon Sonstelie, and participants at a conference on regional government debt in Spain co-sponsored by FEDEA and the Tinker Foundation Inc., and at the 1998 Annual Conference of the National Tax Association, as well as participants in seminars at the University of California, Berkeley, the Bank of Spain, Universitat Pompeu Fabra, the University of Michigan, the University of Illinois at Chicago, and Michigan State University. We wish to thank Diane McCarthy and Esther Pallarols for research assistance.

Contact information: Teresa Garcia-Milà, Department of Economics, Universitat Pompeu Fabra, Ramon Trias Fargas 25-27, 08005 Barcelona SPAIN, 34-93-542-1749, teresa.garcia-mila@econ.upf.es; Timothy J. Goodspeed, Department of Economics, Hunter College, 695 Park Avenue, New York, NY 10021 USA, 1-212-7725434, timothy.goodspeed@hunter.cuny.edu; Therese J. McGuire, Institute of Government and Public Affairs, University of Illinois at Chicago, 815 West Van Buren Street, Suite 525, Chicago IL 60607 USA, 1-312-996-1643, tmcguire@uic.edu. 


\section{Introduction}

As part of a process of democratization, many countries spanning Europe, Latin America, Africa, and Asia are reorganizing their governments by devolving fiscal responsibility and authority to newly empowered regional and local governments. ${ }^{1}$ Although decentralization in each country proceeds differently according to historical circumstances, institutions, cultures, and political realities, in many instances a common feature is that the devolution is incomplete, that is, spending responsibility is devolved but taxing authority remains with the central government. The devolution of fiscal authority tends to be an evolving process as both levels of government gain experience with new responsibilities and new institutional arrangements.

The borrowing decisions of regional and local governments are at once a concern of, and can be greatly affected by the actions of, the central government. In the early 1990 s the high borrowing of regional governments was a concern as Spain attempted to meet the criteria for admission to the European monetary union. More recently Brazil was on the brink of financial collapse as its subnational governments borrowed significant amounts, and Argentina's provinces contributed importantly to the deficit that was partly responsible for the country's recent crisis. Mexico and South Africa also experienced increases in their deficits, in part as a result of a rapid process of decentralization (Rodden, 2001).

${ }^{1}$ For surveys of practices in various countries, see Freire, Huertas, and Darche (1998) on Latin America, do Carmo Oliveira (1998) and Tanzi (1995) on Brazil, Inman (1999) on South Africa, and Fukasako and de Mello (1999) on many emerging economies. See also The Economist (February 7 , 1998, p. 53) for a discussion of Poland. Some European countries with a long tradition of democracy, such as the United Kingdom and Italy, are also undergoing a process of devolution. See Bordignon (1999) on Italy. 
In this paper we explore the sometimes perverse incentives for regional governments that can arise under systems of incomplete and evolving fiscal decentralization. We develop a twoperiod model to analyze the spending, taxing and borrowing decisions of regional governments. These decisions of the regional governments depend crucially on their expectations about the future course of fiscal decentralization. We consider several alternative possibilities for the future evolution of the system and we characterize the efficiency implications of each of the alternatives. The empirical implications of the model are explored using data for regions in Spain.

The paper is divided into four additional sections. Section 2 provides a survey of some of the relevant literature. Section 3 presents an inter-temporal model of regional government borrowing decisions under an evolving system of incomplete fiscal decentralization. In section 4 we describe the recent evolution of federal finance in Spain and expectations about the future development of the system, and we estimate a model of the borrowing decisions of regional governments in Spain. We conclude and draw policy implications in the final section.

\section{Literature survey}

A OECD publication by Fukasaku and de Mello (1999) highlights three important common elements of fiscal decentralization in emerging economies:

First, the devolution of expenditure functions and revenue sources to lower levels of government has been unbalanced .... Second, revenue-sharing arrangements have relied excessively on intergovernmental transfers .... Third and most important, the design of institutional arrangements often allows the loss of central government control over subnational finances, leading to a deterioration of its fiscal position. 
The first aspect cited above results in a mismatch between regional government expenditures and revenues. Regional governments with access to subnational capital markets may issue debt to correct for this mismatch. The second issue can be related to the first in creating a mismatch, but is also suggestive of a more subtle problem involving a break in the link between the benefits and costs of public spending. ${ }^{2}$ If the regional government issues debt because of the first trait, and is financed primarily by central government grants as the second trait indicates, the region may expect the central government to increase its grants in the future in order to pay off the debt. The expectation about future financing is crucial to understanding behavior in the present and is particularly relevant in evolving federations because intergovernmental fiscal relationships are new and changing. The third element referred to above is that institutional arrangements or political pressures may make it difficult for the central government to contain the spending and borrowing of regional governments. This has been a concern in recent years in Spain, Brazil, Argentina, Russia and elsewhere. We explore these issues in this paper.

Our analysis is related to the literature on fiscal federalism surveyed, for instance, in Oates (1994). Winer (1983) studies the separation of benefits and costs in Canadian provinces due to central government financing of regions by grants rather than regional financing using own taxes. He finds that central government financing creates a lower perceived tax-price on the part of Canadian provinces. This finding is reminiscent of the fiscal illusion explanation of the

\footnotetext{
${ }^{2}$ It has long been recognized that when spending responsibility and revenue-raising authority are divorced from one another, governments tend to face incentives that lead to inefficient decisions, emphasized particularly by Buchanan (1967). Oates (1972) states “... it is generally desirable, at least at the margin, to have decentralized levels of government finance programs with their own resources rather than with funds from external sources. If revenues are not raised locally, the explicit link between the benefits and real costs of the programs is broken." (p. 124)
} 
voluminous flypaper effect literature, surveyed by Hines and Thaler (1995), which studies inefficient behavior on the part of lower-level governments that are funded by grants from higher-level governments.

A second related literature studies the effect of institutional rules on borrowing. For instance, Poterba (1995) and Von Hagen (1991) study the effect of U.S. state constitutional rules on borrowing. Others, such as Bird, Ebel, and Wallich (1995), Prud'homme (1995), and Tanzi (1996) argue that the central government needs to impose some sort of rule or constraint on regional borrowing to influence regional government expectations. However, Inman and Rubinfeld (1996) stress that in practice the central government is likely to be influenced by political pressures, so it may be politically difficult to pass a constitutional rule in the first place, or to enforce it at a later date.

A third related literature studies soft budget constraints. This literature, surveyed by Maskin (1999), derives from Kornai’s (1986) analysis of centrally planned economies in which an unprofitable enterprise expects to be bailed out by the central government. Qian and Roland (1998) extend this analysis to federalism in transition economies by analyzing how the incentive to bail out the unprofitable enterprise changes when it is the lower level of government that decides whether or not to bail out the enterprise. Qian and Weingast (1997) argue that, to the extent that subnational governments do not have direct access to the central bank, their budget constraints will be harder than the central government's. However, they also note that central government grants provide a way in which subnational governments may gain indirect access to the central bank, and hence soften regional government budget constraints. We do not study the 
softness of an enterprise's budget constraint, but rather the softness of the regional government's budget constraint.

Wildasin (1997) also studies the softness of the regional government budget constraint. He argues that the central government's objective is to correct for the external impact on the economy as a whole that would result if a lower level government were to go bankrupt. Since the externality is big for large jurisdictions, the central government acts to bail out large lower level governments, but not small ones.

Our analysis combines elements of all of these literatures. We analyze an intertemporal model of regional government spending and borrowing decisions. Beginning with a highly centralized system, we show that the incentives to borrow depend on the future evolution of the fiscal federal system. One interesting finding, obtained for reasons different from the ones already existing in the literature, is that the size of a region influences the incentives to borrow.

\section{A theory of incomplete fiscal decentralization in an evolving federation}

Several countries in various parts of the world have recently begun, and in some cases completed, a process of decentralization. Often the central governments in these emerging democracies have been willing to devolve spending responsibility but hesitant to devolve revenue-raising authority. ${ }^{3}$ Behind this behavior of the central governments may be the desire to maintain political power and economic control in the face of pressures to decentralize. The

\footnotetext{
${ }^{3}$ Spain until recently, Colombia, Argentina and many other Latin American and Eastern European countries are examples of this behavior.
} 
decision to retain revenue-raising authority can become costly as spending by the newly-empowered regional governments grows. If the cost of supporting the regional governments crosses some threshold, the central government may prefer to relinquish revenue-raising authority rather than continue to finance the excessive spending of the regions.

The central government can choose to implement several possible financing schemes consistent with its preferences to retain political and economic control of the regions. The central government could choose to increase grants in response to the expenditure demands of the regions. This decision would be to implement a form of soft budget constraint. A very different possibility is for the central government to devolve taxing authority to the regions. The central government could also decide not to allow regional taxing authority and to hold grants constant regardless of the spending and borrowing behavior of the regions. This last alternative would be a decision to impose a hard budget constraint on the regions. We analyze each of these cases in a two-period inter-temporal model of regional borrowing decisions.

The federation is assumed to consist of a central government and a set of regional governments. The central government decides on an initial level of grants for each region in each of the two periods. This initial decision is exogenous to the model. To provide a rationale for regional borrowing (or lending), it is assumed that this initial exogenous choice of grant level by the central government does not exactly match the demand of the regional government for spending in at least one of the two periods. ${ }^{4}$ The regional government therefore borrows or lends in period one to optimize its inter-temporal consumption decisions.

${ }^{4}$ That the central government lacks enough information to match grants to spending demands of regions is of course a prime rationale for a federal system of government. See Oates (1972). 
We assume that the regional government chooses borrowing in period one to maximize the utility of a representative consumer, takes other regions' borrowing as given, and takes into account future central government behavior. The utility of the representative consumer in region $\mathrm{i}$ is assumed to be a function of private consumption in periods one and two, $\mathrm{C}_{\mathrm{i} 1}$ and $\mathrm{C}_{\mathrm{i} 2}$, and percapita public consumption in periods one and two, $\mathrm{G}_{\mathrm{i} 1}$ and $\mathrm{G}_{\mathrm{i} 2}$. The representative consumer has private income in each period, $\mathrm{Y}_{\mathrm{i} 1}$ and $\mathrm{Y}_{\mathrm{i} 2}$, net of initial (and exogenous) central government tax payments. In addition to the exogenous central government per-capita grants received in each period, $\mathrm{g}_{\mathrm{i} 1}$ and $\mathrm{g}_{\mathrm{i} 2}$, the region is able to borrow an amount per capita for public consumption in period one of $\mathrm{B}_{\mathrm{i} 1}^{\mathrm{G}}$. The representative consumer can borrow an amount for private consumption in period one denoted by $\mathrm{B}_{\mathrm{i} 1}^{\mathrm{C}}$. Each region is a small open economy that takes the interest rate, r, as given.

\section{$\underline{3.1 \text { Hard budget constraint }}$}

We first consider a case in which central government grants for the two periods are pre-announced and regions believe that there will be no change in the financing system in the future. The credibility of a hard budget constraint is based on the reputation of a central government that made no concessions in the past to excessive spending (and borrowing) by the regions. Regional government i's problem is thus ${ }^{5}$ :

${ }^{5}$ We could add a central government budget in periods one and two to account for taxes paid to finance the initial grant levels, but all parts of such a constraint (the initial grants, the central government tax rate that finances such grants, and the total tax base) are exogenous to the model, so this will have no bearing on the results. The model could be extended to include a labor supply or migration response, in which case the central government funding of initial grant levels would become relevant. 


$$
\begin{aligned}
\underset{B_{i 1}^{C}, B_{i 1}^{G}}{\operatorname{Max}} & U_{i}\left(G_{i 1}, C_{i 1}, G_{i 2}, C_{i 2}\right) \\
\text { s.t. } G_{i 1} & =g_{i 1}+B_{i 1}^{G} \\
C_{i 1} & =Y_{i 1}+B_{i 1}^{C} \\
G_{i 2} & =g_{i 2}-B_{i 1}^{G}(1+r) \\
C_{i 2} & =Y_{i 2}-B_{i 1}^{C}(1+r)
\end{aligned}
$$

The first-order conditions can be rearranged to yield the usual inter-temporal efficiency relationship between present and future consumption for private and public good consumption, respectively:

$$
\frac{\frac{\partial U_{i}}{\partial C_{i 1}}}{\frac{\partial U_{i}}{\partial C_{i 2}}}=\frac{\frac{\partial U_{i}}{\partial G_{i 1}}}{\frac{\partial U_{i}}{\partial G_{i 2}}}=(1+r)
$$

The representative consumer is able to smooth both private and public consumption between the two periods through borrowing. Inter-temporal efficiency is achieved: the central government forces the region to face a "hard" budget constraint and the representative consumer in each region considers the true opportunity cost of its borrowing decision, the value of reduced consumption in period two.

The region does not, however, have access to taxes and therefore cannot trade-off public and private consumption. One consequence of this is that contemporaneous efficiency is not necessarily achieve. As is implied by the first order conditions, the marginal rate of substitution between private and public consumption is equal in both periods, but not necessarily equal to the 
marginal rate of transformation. Only in the rare case that the present discounted value of grants allows an optimal allocation between private and public consumption will the solution be efficient overall. A second consequence is that the inter-temporal budget constraint between $\mathrm{G}_{1}$ and $G_{2}$ is independent of private income, $Y$. If utility is separable, this implies that regions with identical preferences and grants but with different per capita incomes will choose the same amount of the public good and borrow identical amounts, so we should not find any empirical relationship between income per capita and borrowing. ${ }^{6}$

\section{$\underline{3.2 \text { Regional taxing authority }}$}

We consider a second case in which the central government devolves taxing authority to the regions in period two. This gives the regions the authority to tax themselves in period two to pay off first period borrowing and/or to increase second period public spending. Second period grants received from the central government remain fixed. This could be considered a likely evolution of the financing scheme of a transition economy that takes the model of a mature decentralized country as a point of reference. Regional government i's problem is:

$$
\begin{aligned}
& \operatorname{Max} U_{i}\left(G_{i 1}, C_{i 1}, G_{i 2} C_{i 2}\right) \\
& B_{i 1}^{C}, B_{i I}^{G}, t_{i 2} \\
& \text { s.t. } G_{i l}=g_{i l}+B_{i l}{ }^{G} \\
& C_{i l}=Y_{i l}+B_{i l}^{C} \\
& G_{i 2}=g_{i 2}+t_{i 2} Y_{i 2}-B_{i 1}^{G}(1+r) \\
& C_{i 2}=Y_{i 2}\left(1-t_{i 2}\right)-B_{i 1}^{C}(1+r)
\end{aligned}
$$

${ }^{6}$ Assuming that the public good is normal, rich regions will have higher levels of dissatisfaction with the resulting levels of public good consumption. 
The third and fourth constraints assume that the region can impose a proportional income tax at rate $t_{\mathrm{i} 2}$ in the second period.

The first-order conditions can be rearranged to yield the usual inter-temporal efficiency relationship between present and future consumption for private and public good consumption, respectively:

$$
\frac{\frac{\partial U_{i}}{\partial C_{i 1}}}{\frac{\partial U_{i}}{\partial C_{i 2}}}=\frac{\frac{\partial U_{i}}{\partial G_{i 1}}}{\frac{\partial U_{i}}{\partial G_{i 2}}}=(1+r)
$$

and the contemporaneous marginal conditions between public and private consumption for each period:

$$
\frac{\frac{\partial U_{i}}{\partial G_{i 1}}}{\frac{\partial U_{i}}{\partial C_{i 1}}}=\frac{\frac{\partial U_{i}}{\partial G_{i 2}}}{\frac{\partial U_{i}}{\partial C_{i 2}}}=1
$$

Since the contemporaneous marginal rate of transformation between public and private goods is also one, this solution is contemporaneously as well as inter-temporally efficient.

This case illustrates that subnational capital markets can perform the important function of helping to correct for an initial misallocation of grants by the central government. If the central government initially allocates an insufficient level of grants to a region, and the region can impose taxes in the future to raise additional funds, the region will borrow to cover the gap between its allocated grants and its desired level of spending. As before, the region takes into 
account the true opportunity cost of its borrowing decision, i.e., foregone second period consumption, so an efficient inter-temporal solution is achieved. However, unlike the first case, the region can impose taxes in the future to raise additional funds; it is therefore able to trade-off private and public consumption, and contemporaneous efficiency is also achieved.

A graphical depiction of the solution in terms of demand for public spending in period one is illustrated in Figure 1. (The i subscript has been suppressed.) The region will equate the representative consumer's demand, represented by $\mathrm{U}_{\mathrm{Gl}} / \mathrm{U}_{\mathrm{Cl}}$, to the ratio of prices he faces, one. The region is given $g_{1}$ per capita from the central government to spend on $\mathrm{G}_{1}$. If this leaves the representative consumer off of his or her demand curve, the region will borrow (or save) until the representative consumer just satisfies his or her demand. Figure 1 illustrates the case in which the region is given too little in the way of grants and borrows the difference between the desired demand of the representative consumer, $\mathrm{G}_{1}{ }^{*}$, and the per capita grant level. Assuming the public good is a normal good, the optimal amount of borrowing will be higher for regions with higher incomes, all else equal. ${ }^{7}$

\section{$\underline{3.3 \text { Soft budget constraint }}$}

Under a soft budget constraint, region i expects the central government to provide in the second period funds in addition to the grants originally announced. In particular we focus on the case where these additional funds are provided by the central government in response to regional borrowing. The central government will rescue ex-post part or all of the regional borrowing, and

\footnotetext{
${ }^{7}$ In our model, there is no efficiency cost of either borrowing or taxes; that is, first-period taxation and first-period borrowing are perfect substitutes. If there were some efficiency cost to borrowing, such as an increase in the carrying costs of debt, and if taxes were available in the first period, the region would increase its reliance on taxes and reduce its reliance on debt finance.
} 
the regions believe in advance that it will do so. ${ }^{8}$ We assume that region $\mathrm{i}$ has some expectation not only of central government behavior with respect to its own grant allocation, but also of central government behavior with respect to other regions' grant allocations, and that this expectation is correct. This new set of grants can be represented by the following general function:

$$
g_{j 2}^{B}=f_{j}\left(B^{G}\right)(1+r), \quad f_{j}, f^{\prime}{ }_{j} \geq 0 \quad \text { for all } j
$$

where $\mathrm{g}_{\mathrm{j} 2}^{\mathrm{B}}$ is the additional amount of per-capita grants that the central government is expected to give to region $\mathrm{j}$ and $\mathrm{B}^{\mathrm{G}}$ is a vector $\left(\mathrm{B}_{11}^{\mathrm{G}}, \ldots, \mathrm{B}_{1 \mathrm{~m}}^{\mathrm{G}}\right)$ of first-period borrowing by each of the $\mathrm{m}$ regions. We assume that the region does not expect the central government to decrease grants as it or any other region increases borrowing $\left(f^{\prime} \geq 0\right)$ nor does it expect any region to receive negative grants ( $f \geq 0$ ). Any increase in grants is assumed to be funded by a proportional income tax imposed by the central government in the second period.

Regional government i's problem is:

${ }^{8}$ The rationale for such behavior of the central government is justified when the cost to the central government of not providing additional funds exceeds the cost of providing them (Inman (forthcoming)). 


$$
\begin{aligned}
& \underset{B_{i l}^{C}, B_{i 1}^{G}}{\operatorname{Max}} U_{i}\left(G_{i 1}, C_{i 1}, G_{i 2}, C_{i 2}\right) \\
& \text { s.t. } G_{i 1}=g_{i 1}+B_{i 1}^{G} \\
& C_{i 1}=Y_{i 1}+B_{i 1}^{C} \\
& G_{i 2}=g_{i 2}+g_{i 2}^{B}-B_{i 1}^{G}(1+r) \\
& C_{i 2}=Y_{i 2}\left(1-t_{2}^{c}\right)-B_{i 1}^{C}(1+r) \\
& t_{2}^{c} \sum_{j=1}^{m} n_{j} Y_{j 2}=\sum_{j=1}^{m} n_{j} g_{j 2}^{B} \\
& g_{j 2}^{B}=f_{j}\left(B^{G}\right)(1+r) \text { for all } j
\end{aligned}
$$

where $n_{i}$ is the population of region $i$, the fifth constraint represents the additional taxes levied by the central government necessary to finance any increase in second period grants, and the sixth set of $\mathrm{m}$ constraints is region i's expectation of additional second period grants for every region $\mathrm{j}$. The first-order conditions yield

$$
\frac{\frac{\partial U_{i}}{\partial G_{i 1}}}{\frac{\partial U_{i}}{\partial C_{i 1}}}=\frac{1}{1+r} Y_{i 2} \sum_{j=1}^{m} \frac{\partial t_{2}^{C}}{\partial f_{j}} \frac{\partial f_{j}}{\partial B_{i 1}^{G}}+\frac{\frac{\partial U_{i}}{\partial G_{i 2}}}{\frac{\partial U_{i}}{\partial C_{i 2}}}\left(1-\frac{\partial f_{i}}{\partial B_{i 1}}\right)
$$

When a region considers borrowing an extra dollar on behalf of its representative agent, the price it faces reflects two forces. The first term of equation (14) captures the fact that the taxes paid by the representative agent to the central government will increase to finance the additional grants triggered by the region's marginal borrowing. Taxes may increase by less than a dollar because agents of all other regions contribute through central taxes to paying off the debt. The final price of borrowing also depends on the amount of additional funds that each region 
obtains per capita. This effect is reflected in the second term, which is smaller the larger is the increase in central grants that the representative agent will receive as a result of the borrowing decision. Central grants will increase by some or all of the extra dollar of borrowing and will be distributed back to the region to compensate (perhaps only partially) for the borrowing. The exact amount of each term depends on the functional form of $\mathrm{f}_{\mathrm{j}}\left(\mathrm{B}^{\mathrm{G}}\right)$. We analyze two cases that are of interest from both a theoretical perspective and a policy perspective.

\section{3a Central government assumes each region's debt}

We analyze here the case where the region expects the central government to increase second period grants dollar for dollar (in present value) with the region's first period borrowing. The grant formula is $\mathrm{f}_{\mathrm{j}}\left(\mathrm{B}^{\mathrm{G}}\right)$ equals $\mathrm{B}^{\mathrm{G}}{ }_{\mathrm{j} 1}$. The first order conditions become:

$$
\frac{\frac{\partial U_{i}}{\partial G_{i 1}}}{\frac{\partial U_{i}}{\partial C_{i 1}}}=\frac{n_{i} Y_{i 2}}{\sum_{j} n_{j} Y_{j 2}}
$$

The second term of equation (14) is zero in this case because there is no extra loss or gain in the grant distribution: regional grants increase dollar for dollar with borrowing $\left(\partial \mathrm{f}_{\mathrm{i}} / \partial \mathrm{B}_{\mathrm{i} 1}=1\right)$. Thus, the cost for the region of an additional dollar of government consumption is only the taxes that the region pays to the central government, and this tax price is equal to the region's share of national income. The price of first period public consumption is less than one because the region shares the tax consequences of its borrowing with all other regions. This is the well-known problem of the commons, where each region fully internalizes the benefit of additional public consumption, but only internalizes partially its social cost. In effect, the income of all other 
regions is viewed as common property that can be appropriated by borrowing. As Figure 2 illustrates, the lower price leads to greater than efficient demand for public spending in period one and hence excessive borrowing.

All regions have an extra incentive to borrow in this case, as the price of their public consumption in the first period is lower than if the central government did not assume the region's debt. The fall in price, and therefore the strength of the incentive for excessive borrowing per capita, is larger for regions with smaller economies.

\section{$\underline{3.3 \mathrm{~b} \text { Rescue in the aggregate }}$}

Motivated by our understanding that a complete rescue of regional borrowing by the central government may be an unlikely event, but that some changes in the allocation of grants are likely to occur related to the excess needs demonstrated by the regions through borrowing, we analyze a final case. We assume each region expects the central government to increase second period grants to all regions by an amount equal to (or related to) the aggregate borrowing of all regions, responding to the revealed needs of the regions and the political pressures they place on the central government. The distribution of the additional amount among regions is done in proportion to each region's population, reflecting share formulas observed in many countries, which are heavily based on per capita criteria. Two characteristics define the grant rule: each region's borrowing affects the amount to be finally distributed to every other region, and a predetermined criterion is used to distribute the additional funds. In this case

$$
f_{j}\left(B_{11}^{G}, \ldots B_{m l}^{G}\right)=\frac{1}{\sum_{j} n_{j}} \sum_{j} n_{j} B_{j l}^{G}
$$


The first-order conditions can be written as

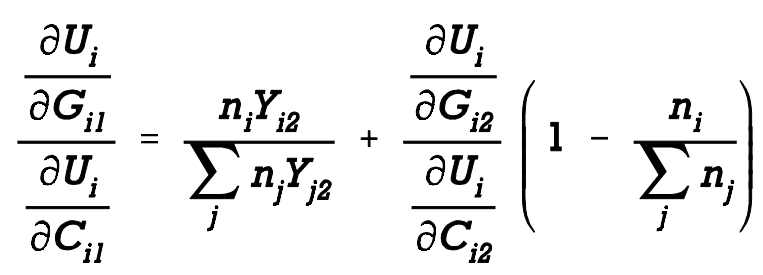

The first term in the price equation is identical to the previous case of full assumption of debt by the central government. As in that case, when a region decides to borrow an extra dollar on behalf of its representative agent, aggregate grants will increase by the population of the region. The representative agent will contribute to the corresponding increase in total taxes in proportion to his or her income. This reduces this part of the price below one and the more so the smaller the economy of the region.

The second component of the price term reveals that the price faced by a region depends on a region's population share. When a region chooses to borrow an extra dollar on behalf of its representative agent, that marginal decision is made for all of its $n$ residents. Because the central government has promised to increase aggregate grants in response to aggregate borrowing, central grants will increase by the population of the borrowing region. According to the grant formula, this increase in the central grants pie will be distributed on a per capita basis throughout the country. Thus, each region will receive on behalf of each of its residents $n_{i} / \sum n_{j}$ in increased grants when a region of size $n_{i}$ chooses to borrow at the margin. The incentive to borrow is, therefore, greater the larger the region because the grant pie increases more when a larger region borrows. 
There are two forces at work rendering the price of borrowing different from one: the share of income and the share of population. The two forces are related to the size of the region and influence the price with opposing effects - the greater the share of income the greater the tax cost of borrowing and the greater the share of population the greater the grant benefit of borrowing. This result, that population (and size more generally) matters for borrowing decisions is due to reasons completely separate from the "too big to fail" argument (see Wildasin, 1997). In fact, in the case we analyze the result follows from an equal per capita treatment of all citizens, regardless of whether they live in a large or a small region. In many respects it is the opposite of the "too big to fail" idea in which the central government rescues large regions with higher probability, and therefore favors citizens of those regions. When large regions borrow their per capita decisions have a larger impact on central taxes owed and grants received relative to the impact when smaller regions borrow. The price faced by a region reflects these two phenomena and thus the size of the region undertaking the borrowing will affect the incentives faced by the region.

\section{Empirical results: a case study of Spain}

\section{$\underline{4.1}$ Fiscal decentralization in Spain}

Spain presents a particularly pertinent case for testing the implications of our theoretical model because its system of fiscal decentralization is relatively new, incomplete and evolving. A process of devolution has been occurring in Spain since the death of Franco in 1975 and the creation of a democratic Constitution in 1978. Seventeen regional governments (called Autonomous Communities) have been given varying degrees of spending responsibilities and 
taxing authority. While the degree of regional fiscal autonomy has slowly increased over time, the central government still retains control over the vast majority of revenues available to the regional governments. ${ }^{9}$ Fifteen of the regions are regulated by what is known as the Common Regime and share the same financing scheme but have different levels of spending responsibility, higher for those regions with stronger cultural and historical identities. For historical reasons, Navarra and País Vasco have a special status called the Foral Regime, which is based on regional collection of taxes and payments to the central government according to the cost of services that the central government provides. Because the arrangements for these two regions differs so dramatically from the arrangement for the other fifteen, we omit them from our discussion and analysis.

In Table 1 we illustrate the different types of arrangements for the fifteen regions during our sample period and display income per capita for each region. The fifteen regions are divided into two groups; ten have responsibility for a variety of minor services such as housing policy, culture, and protection of the environment, and five have responsibility for these services as well as the major services of health and education. ${ }^{10}$ Among the ten low-responsibility regions, five are multi-provincial meaning that there is an additional level of sub-regional government (roughly equivalent to a U.S. county) with some spending authority. Among the five high-

${ }^{9}$ This is particularly true for the period of our sample, 1984-1995. Since 1997 the system has evolved towards a higher degree of fiscal autonomy for the regions. The latest reform, effective in 2002, further devolves revenue autonomy to regions, although the effective impact of that reform is not yet clear.

${ }^{10}$ As of January 2002 education had been transferred to all regions, and health was in the process of being transferred. 
responsibility regions is one of the poorest (Andalucía) and one of the richest (Cataluña); the ten low-responsibility regions include the poorest (Extremadura) and the richest (Baleares) regions.

For the regions under the Common Regime there are three primary sources of revenue, two of which are in large part set by the central government. The first source, centrally provided grants to the regions, consists of two types. One type, the Interterritorial Compensation Fund (FCI), is largely redistributive. The other type, which is much more significant for most regions, provides grants according to the spending responsibilities that have been devolved to the regions. Essentially, the central government attempts to determine the costs per capita of providing various services and then gives a grant to regions using a formula based on factors such as population, land area, and number of administrative units. ${ }^{11}$ A third source of grant revenues for the regions is the European Union. These EU grant revenues are significant for some regions. ${ }^{12}$

A second source of revenues is certain taxes that have been ceded to the regions by the central government. For the sample period this source of revenue is also under the control of the central government because the tax bases and rates are largely set by the central government. ${ }^{13}$ In addition, central grants are in large part net of ceded taxes rendering the taxes minor sources of own-source revenue. Recently the system has been evolving to allow greater regional control of the income tax and partial devolution of indirect taxes, but these changes are not relevant for the

\footnotetext{
${ }^{11}$ The regional government of the uniprovincial regions is in charge of spending responsibilities that in other regions are the responsibility of sub-regional provincial governments. Uniprovincial regions receive grants that in other regions go to the provincial governments.

${ }^{12}$ See Garcia-Milà and McGuire (2001) for a more in-depth description of intergovernmental grants in Spain.

${ }^{13}$ In some instances, regions can impose surcharges on the rates.
} 
period we study, except for their influence on expectations about the future evolution of the system. The third source of revenue is borrowing, which, subject to a limit set by the central government on the amount of debt servicing, is largely under the control of the regional governments.

Table 2 displays the percentage of total revenues attributable to each source for each regional government on average over the period 1984-1995. Because of the dependence of central grants on the different levels of spending responsibility and the presence of the redistributive grants both from the central government and the European Union, the proportion of funding from grants varies a great deal from region to region. On average, summing grants and ceded taxes, nearly 90 percent of total regional revenues are not under the control of the regions. The only significant source of revenue under the control of the regions is borrowing, which has contributed about 10 percent of regional revenues on average over the period. This system of finance is in marked contrast to the system of fiscal federalism in the U.S. in which regional governments have significant taxing authority.

Regional governments began to rely on borrowing as a source of revenue in the mid 1980s and its importance as a revenue source has increased over time. Because of the rapid increase in borrowing over the decade analyzed, the ratio of debt service to non-capital revenues has grown from three percent in 1984 to nearly ten percent in 1995 on average (see Table 3). The central government limits this ratio to no greater than 25 percent. In the three years displayed in Table 3 no region except for Cantabria in 1995 had violated this limit, but several had come close. 
Table 4 displays annual observations for income per capita, total revenue per capita and deficit per capita for the aggregate of the fifteen regions from 1984 to 1995 . Clearly, by these measures, the size of the regional government sector relative to the private sector rose over the period with average annual increases of ten percent for total revenue per capita and only three percent for income per capita. Deficit spending per capita increased from a small surplus to a peak of 18,563 pesetas in 1992 to close out the period at 9,622 pesetas.

Taken together these facts suggest that Spain may be a good fit with our model. The facts indicate the heavy reliance on grants and the increasing role of borrowing and debt in the finances of the regional governments in Spain. It is also the case that the evolution of the decentralization process has elements that are consistent with our characterization of the future in the theoretical model developed in the previous section. Since 1997 regional governments have been able to choose to substitute a percentage of the income tax raised in their region for part of their grants. The latest revision of the system, effective in January 2002, devolved one third of the personal income tax and the value added tax, as well as special taxes on gas, alcohol or tobacco. It also eased many of the restrictions on establishing rates and exemptions for the ceded taxes (except for the value added tax and the special taxes that are regulated by the European Union). With these latest changes, regional expectations that taxes would be devolved have been partly fulfilled. In addition, for some regions and types of expenditures, additional grants were given to cover the historical debt that had been accumulated due to an inadequacy of grant revenues relative to expenditures; this is a dollar-for-dollar increase in grants in response to borrowing, at least for part of the debt. Finally, the amount transferred by the central government is increasing, annually negotiated, and has responded to the pressures of various regional 
governments to obtain more funds. These funds have usually been distributed using the same criteria as the original funds, where population is the main driving parameter among regions with similar expenditure responsibilities. This behavior of the central government is similar to an increase in aggregate grants in response to an increase in aggregate borrowing that gets distributed according to population.

\subsection{Empirical implications of the theory}

We seek to understand and explain regional borrowing behavior in Spain. Depending on the regional governments' expectations for the future, our model predicts relationships between borrowing and various variables that capture the characteristics of demand and of the evolving fiscal federal system.

As illustrated in Figure 1, if regions expect the system to evolve in such a way that they have access to additional revenues in the future, they will borrow an amount equal to the difference between desired spending and grants. Assuming the demand for the public good is normal and holding grants per capita constant, richer regions will want to borrow more than poorer ones. Alternatively, holding income per capita constant and for regions with the same level of spending responsibility, regions receiving larger grants per capita will borrow less than regions receiving relatively small grants. Therefore, unless regions expect to face a hard budget constraint in the future, we should expect to find that borrowing per capita has a negative relationship with grants per capita and a positive one with income per capita. ${ }^{14}$

\footnotetext{
${ }^{14}$ If regions expect a hard budget constraint, our model implies no relationship between borrowing per capita and the variables of interest.
} 
If regions expect future grants to increase dollar for dollar with present borrowing, the price of borrowing is less than one (the efficient price). Even though the region's debt is totally covered by grants from the central government the price does not fall to zero because there are tax implications associated with grant financing of borrowing. When a region chooses to borrow an extra dollar per capita on behalf of its representative agent, central grants and therefore central taxes will have to increase by an amount equal to the population of the region. Because we assume a linear income tax, the amount of taxes owed to the central government by the representative agent associated with an extra dollar of borrowing is equal to the region's share of national income. The price faced by the representative agent is equal to the relative size of the region as measured by the region's share of national income. We thus expect to find a negative relationship between borrowing per capita and income share of the region if the regional governments expect the central government to increase grants dollar for dollar with borrowing.

Finally, if regions expect the central government to increase total grants to cover total borrowing and to allocate the grants on a per-capita basis, the price of borrowing has two components. The first component is the income share of the region. As in the previous case, if the regional government chooses to borrow an extra dollar per capita, central taxes will have to increase by an amount equal to the population of the region, and thus the price will depend on the region's share of income. The second component of price is a function of the population share of the region. When the regional government chooses to borrow an extra dollar per capita, the central government grant pie will increase by an amount equal to the size of the region. The bigger the region the greater the impact on overall grants and thus the greater the incentive to 
borrow. For this component, the greater the size of the region as measured by population share the lower the price.

Depending on regional governments' expectations about the evolution of the fiscal system, the theory implies relationships between borrowing and income per capita, grants per capita, the share of income, and the share of population. Income per capita and grants per capita influence the amount by which desired demand exceeds grants and therefore the amount of borrowing. The share of income and the share of population characterize the price of borrowing under expectations of some form of soft budget constraint.

\section{$\underline{4.3 \text { Results }}$}

We use annual observations for fifteen regions in Spain (all but Navarra and País Vasco) over the period 1984-1995 to test the implications of our model. ${ }^{15}$ To control for higher levels of grants from the central government associated with having responsibilities for health and education, we include dummy variables indicating whether and when a region has such responsibilities. ${ }^{16}$ Analogously, we include a dummy variable for those low-responsibility regions that are uni-provincial. These five regions have responsibility for sub-regional spending that the multi-provincial regions do not. Finally, we include annual time dummies to capture

\footnotetext{
${ }^{15}$ Data sources are described in an appendix.
}

${ }^{16}$ Dummies for both health and education are needed because, while all high-responsibility regions were responsible for education over the time period analyzed, health was devolved at different times for different regions (Andalucia and Cataluña had responsibility for health throughout the period; C. Valenciana gained responsibility in 1988, Galicia in 1991, and Canarias in 1994). 
general trends over the period in borrowing and general time-varying factors affecting borrowing, such as the interest rate. ${ }^{17}$

We have reason to expect that the relationship between borrowing and our income and price variables will be different for the five high-responsibility regions and the ten lowresponsibility regions. The five high-responsibility regions have responsibility for two important and relatively income elastic categories of spending-health and education-while the categories of spending common to all regions are likely to be less income elastic. The relationship between borrowing and the price variables may differ across the two types of regions as the price elasticity of demand may differ between the two. We therefore estimate a general model that allows for different slopes for the two types of regions for both income per capita and the variables that influence price, and we test whether the different slopes are supported by the data.

We consider the possibility that regional characteristics not captured by our explanatory variables may have an influence on borrowing decisions, and, if so, we test whether a fixedeffects or random-effects specification is more appropriate. The specification tests indicate that region-specific effects are present. The Hausman tests do not reject the random-effects specification.

The main problem we encounter is that the two share variables, income share and population share, are very similar variables (essentially each represents size of the region) with theoretically opposing effects on borrowing. Recall that the size of the region affects the price of

\footnotetext{
${ }^{17}$ While theory suggests including interest rates faced by the regions, it appears that a priori interest rates are essentially identical across regions, possibly because the markets recognize that ultimate responsibility for regional debt lies with the central government. The ex-post effective cost of debt varies across regions due to their different debt structures, but these differences are not relevant for our analysis.
} 
borrowing positively through the channel of the impact of borrowing on central taxes. Size affects the price of borrowing negatively through the channel of the impact of borrowing on central grants. We measure one size component by income share and the other by population share, but these particular measures of size are partly artifacts of the types of tax and grant formula assumed and either variable could represent either (opposing) size effect. Given this, we estimate equations with one share variable at a time and let the data tell us which effects are operating. The results are displayed in Table 5 .

We find that income per capita has a positive and significant effect on borrowing per capita for the five high responsibility regions. This is consistent with the idea that the grants received by these regions are insufficient to meet their demands and is supported by the notion that the demand for education and health is income elastic. ${ }^{18}$ The variable is not significant for the ten low responsibility regions. This, too, is consistent with the theory if one considers that grants per capita are likely to be large relative to demand for these regions (because the European Union and FCI grants contribute a large amount to fill the gap between desired spending and the central grant designed to support regional spending,) and that the income elasticity of demand is lower for these regions.

Income share (equation 1) and population share (equation 2) have essentially the same effect in both equations: negative and insignificant for the ten low responsibility regions and positive and significant for the five high responsibility regions. For the five high responsibility regions this result is consistent with the regions having an expectation that the evolution of the

${ }^{18}$ Previous studies of the Spanish federal system of government have also found evidence of a likely mismatch of expenditures and revenues. See Garcia-Milà and McGuire (1991, 1993) and Goodspeed (1994). 
fiscal system will entail a rescue in the aggregate, and that the regions place greater weight on, or care more about, the impact of their own borrowing on future grants than the impact of their own borrowing on future taxes. From the perspective of the regional government, the representative agent tends to blame the central government for the tax cost, with essentially zero political cost for the regional government, while the representative agent links the benefits yielded by higher grants to the actions of the regional government. Therefore regional government borrowing decisions may respond more strongly to that part of the price that yields political benefits and less strongly or not at all to the component that has no direct impact on the evaluation of the regional government.

The negative and insignificant coefficients on the size variables for the ten low responsibility regions are also consistent with the theory. An explanation for the insignificance of the variables is that the countervailing size effects cancel one another out. The low responsibility regions tend to receive relatively smaller grants and thus the grant component of the price is not as important to them. In contrast, the tax component is of equal importance for both groups.

Our results seem to indicate that regions in Spain do not perceive a hard budget constraint, but rather expect that the financing scheme will evolve towards higher revenue responsibilities and/or larger grants linked to their borrowing patterns. The evidence in support of these beliefs is stronger for the high responsibility regions than for the low responsibility regions. If regions do, in fact, expect some form of soft budget constraint in the future as suggested by the evidence, then regional borrowing levels may be inefficiently high. 


\section{Conclusion}

Devolution is occurring in many countries around the globe as part of a transition from dictatorships to democracies. Oftentimes, spending responsibilities and borrowing authority are devolved but taxing authority, at least initially, remains with the central government, and regional governments are financed primarily by way of central government grants. We study the consequences of this incomplete and evolutionary method of decentralization; these consequences depend crucially on how the regional governments expect the federation to evolve.

One consequence of initially deficient grant revenues is the tendency for regional governments to rely on debt. If the regional government expects to be granted taxing authority in the future, sub-national capital markets can provide an efficient means to correct any initial revenue deficiency. However, regional borrowing decisions can become distorted if the region expects the central government to increase grants in response to regional borrowing, creating a soft budget constraint for the region. We show that if the region expects a soft budget constraint in the future, the price of borrowing may be inefficiently low resulting in excessive borrowing. This occurs because regions are only partially responsible for their own borrowing.

We examine the implications of the model using data on Spanish regions for the period 1984-1995. Spain in many ways displays the problems typical of a federation that has evolved from a previously centralized form of government. The results of our empirical investigation indicate that among certain Spanish regions, higher income results in greater borrowing, indicating an initial mismatch in grants and desired expenditure. Certain regions also seem to perceive and respond to the inefficient price imbedded in the Spanish system of incomplete fiscal 
devolution. The evidence indicates that regions expect to be bailed out or rescued somehow by the central government and thus they face incentives to borrow inefficiently.

Our analysis of the incentives created by the intergovernmental fiscal system in Spain has important policy implications for other countries undergoing a process of decentralization. The reluctance of central governments to devolve revenue authority may result in inefficient spending and borrowing decisions by lower level governments. The surest path to efficient decision making is to link spending and taxing responsibilities by devolving taxing authority on the heels of the devolution of expenditure responsibility. As fiscal decentralization unfolds around the world it is important to understand the consequences of different fiscal federal arrangements for borrowing and debt and for the efficient allocation of resources. 


\section{References}

Bird, Richard, R. Ebel, and C. Wallich. 1995. "Fiscal decentralization: From command to market." in R. Bird, R. Ebel, and C. Wallich, editors, Decentralization of the socialist state: Intergovernmental finance in transition economies. The World Bank.

Bordignon, Massimo, 1999. "Problems of soft budget constraints in intergovernmental relationships: The case of Italy.” Unpublished.

Buchanan, James M. 1967. Public Finance in Democratic Process. Chapel Hill: University of North Carolina Press.

do Carmo Oliveira, João. 1998. "Financial crises of subnational governments in Brazil." unpublished. The World Bank.

The Economist. "Poland's devolutionary battleground." February 7, 1998, p. 53.

Freire, Maria E., Marcela Huertas, and Benjamin Darche. 1998. Sub-national Access to Capital Markets: The Latin American Experience. Unpublished. The World Bank.

Fukasaku, Kiichiro and Luiz R. de Mello, Jr., editors. 1999. Fiscal decentralization in emerging economies. Paris: OECD.

Garcia-Milà, Teresa, and Therese J. McGuire. 1991. "The Effects of Central Government Financing on Regional Government Expenditures in Spain." in Public Finance with Several Levels of Government. Rémy Prud'homme, editor. The Hague: Foundation Journal Public Finance.

Garcia-Milà, Teresa, and Therese J. McGuire. 1993. "Evaluación del Régimen de Financiación de las Comunidades Autónomas a Través de un Análisis del Gasto y la Renta." Revista de Economía Aplicada. 1(3): 5-26.

Garcia-Milà, Teresa, and Therese J. McGuire. 2001. "Do Interregional Transfers Improve the Economic Performance of Poor Regions? The Case of Spain." International Tax and Public Finance. 8(3).

Goodspeed, Timothy J. 1994. "Efficiency and Equity Consequences of Decentralized Government: An Application to Spain." International Tax and Public Finance. 1: 35-54.

Hines, James R., Jr. and Richard Thaler. 1995. “The Flypaper Effect.” Journal of Economic Perspectives. 9:217-26. 
Inman, Robert, "Hard and Soft Budget Constraints in the United States", in Fiscal Decentralization and the Challenge of Hard Budget Constraints, Rodden et.al. editors, forthcoming Fall 2002, MIT Press.

Inman, Robert. 1999. "On Designing Intergovernmental Transfers with an Application in the New South Africa." in A. Panagariya, P. Portney, and R. Schwab, eds., Environmental and Public Economics: Essays in Honor of Wallace E. Oates, Edward Elgar, Northhampton, MA, pp. 222-252.

Inman, Robert, and Daniel Rubinfeld. 1996. "Designing tax policies in federalist economies: An overview." Journal of Public Economics. 60: 307-334.

Kornai, Janos. 1986. “The Soft Budget Constraint.” Kyklos. 39(1):3-30.

Maskin, Eric S. 1999. "Recent theoretical work on the soft budget constraint." American Economic Review. May. 421-425.

Oates, Wallace E. 1972. Fiscal Federalism. New York: Harcourt Brace Jovanovich, Inc.

Oates, Wallace E. 1994. "Federalism and government finance." in J. Quigley and E. Smolensky, eds. Modern Public Finance. Cambridge: Harvard University Press.

Poterba, James M. 1995. "Capital Budgets, Borrowing Rules, and State Capital Spending." Journal of Public Economics. 56: 165-187.

Prud'homme, Rémy. 1995. "The dangers of decentralization." The World Bank Research Observer. 10: 201-220.

Qian, Yingyi and Gérard Roland. 1998. "Federalism and the soft budget constraint." American Economic Review. December: 1141-1162.

Qian, Yingyi and Barry Weingast. 1997. "Federalism as commitment to preserving market incentives." Journal of Economic Perspectives. 11. 4: 83-92.

Rodden, Jonathan, "The Dilemma of Fiscal Federalism: Grants and Fiscal Performance around the World", 2001, mimeo, MIT.

Tanzi, Vito. 1996. "Fiscal Federalism and Decentralization: A Review of Some Efficiency and Macroeconomic Aspects," in M. Bruno and B. Pleskovic, eds. Annual World Bank Conference on Development Economics 1995. Washington: The World Bank.

Von Hagen, Jurgen. 1991. "A Note on the Empirical Effectiveness of Formal Fiscal Restraints." Journal of Public Economics. 44: 199-210. 
Wildasin, David. 1997. "Externalities and Bailouts: Hard and soft budget constraints in intergovernmental fiscal relations." unpublished.

Winer, Stanley. 1983. "Some evidence on the effect of the separation of spending and taxing decisions." Journal of Political Economy. 91: 126-140. 


\section{Appendix: Data Sources}

Our measure of borrowing is the sum of all revenues except "Pasivos financieros" minus the sum of all expenditures, including interest and principal payments of outstanding debt. Revenues are chapters I through VIII of "Derechos reconocidos" and expenditures are chapters I through IX of "Obligaciones reconocidas" from Liquidación de los Presupuestos de las Comunidades Autónomas, published by the Dirección General de Coordinación con las Haciendas Territoriales of the Ministerio de Economía y Hacienda.

Income is "Valor añadido bruto a precios de mercado" (gross value added at market prices) from Contabilidad Regional de España.

The grant variable that appears in the regression is capturing all revenues of the regions that are not from borrowing, and therefore are chapters I through VIII of "Derechos reconocidos" from Liquidación de los Presupuestos de las Comunidades Autónomas, published by the Dirección General de Coordinación con las Haciendas Territoriales of the Ministerio de Economía y Hacienda. This variable includes European Union grants received by the regional government.

Population is "Población de derecho" from Anuario Estadístico de España, published by Instituto Nacional de Estadística (INE).

All variables, except population, are in constant 1986 pesetas, deflated using the Spanish GDP deflator. 
Figure 1

Equilibrium Borrowing under Regional Financing

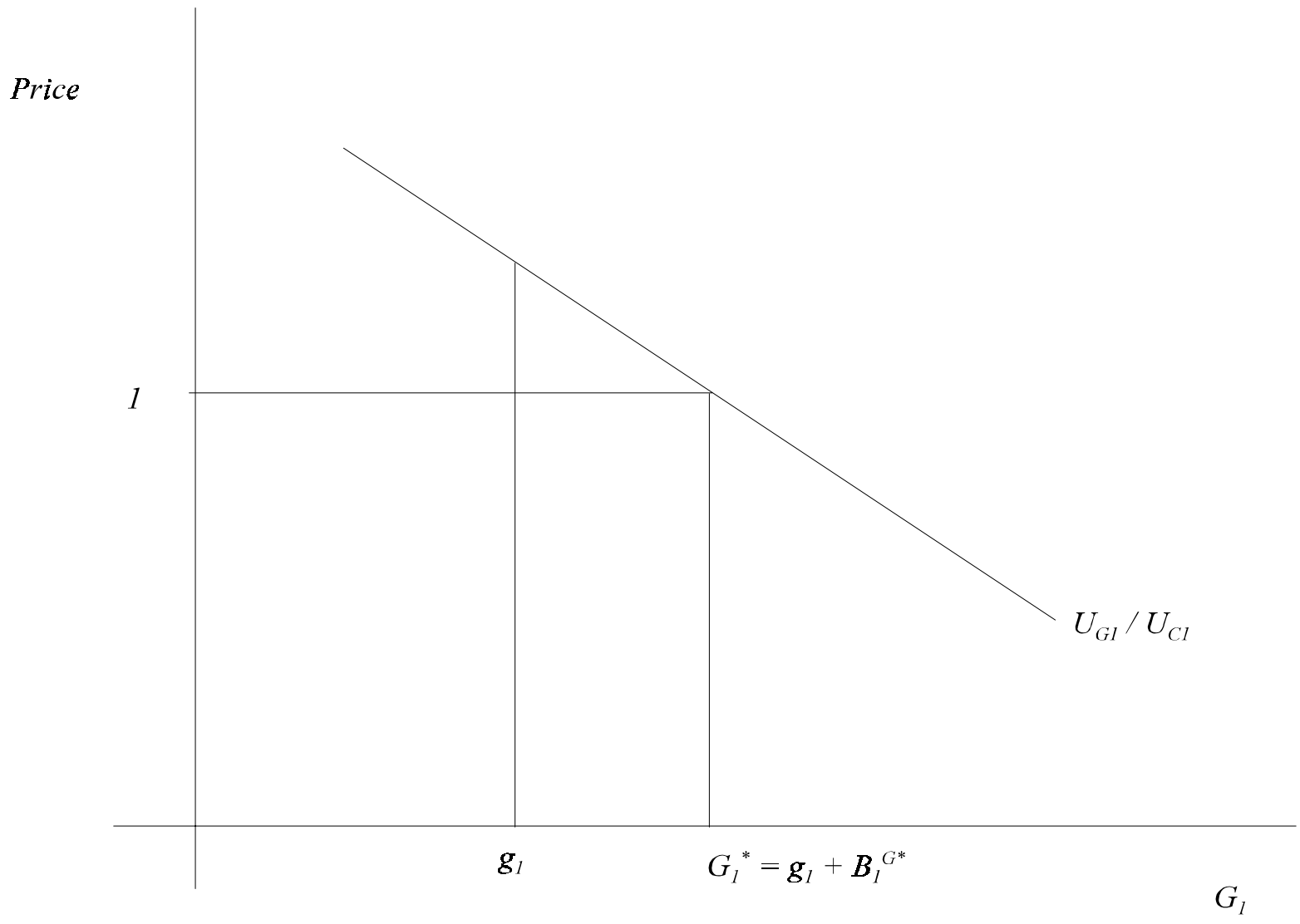


Figure 2

Equilibrium Borrowing under Central Government Financing of Regional Borrowing

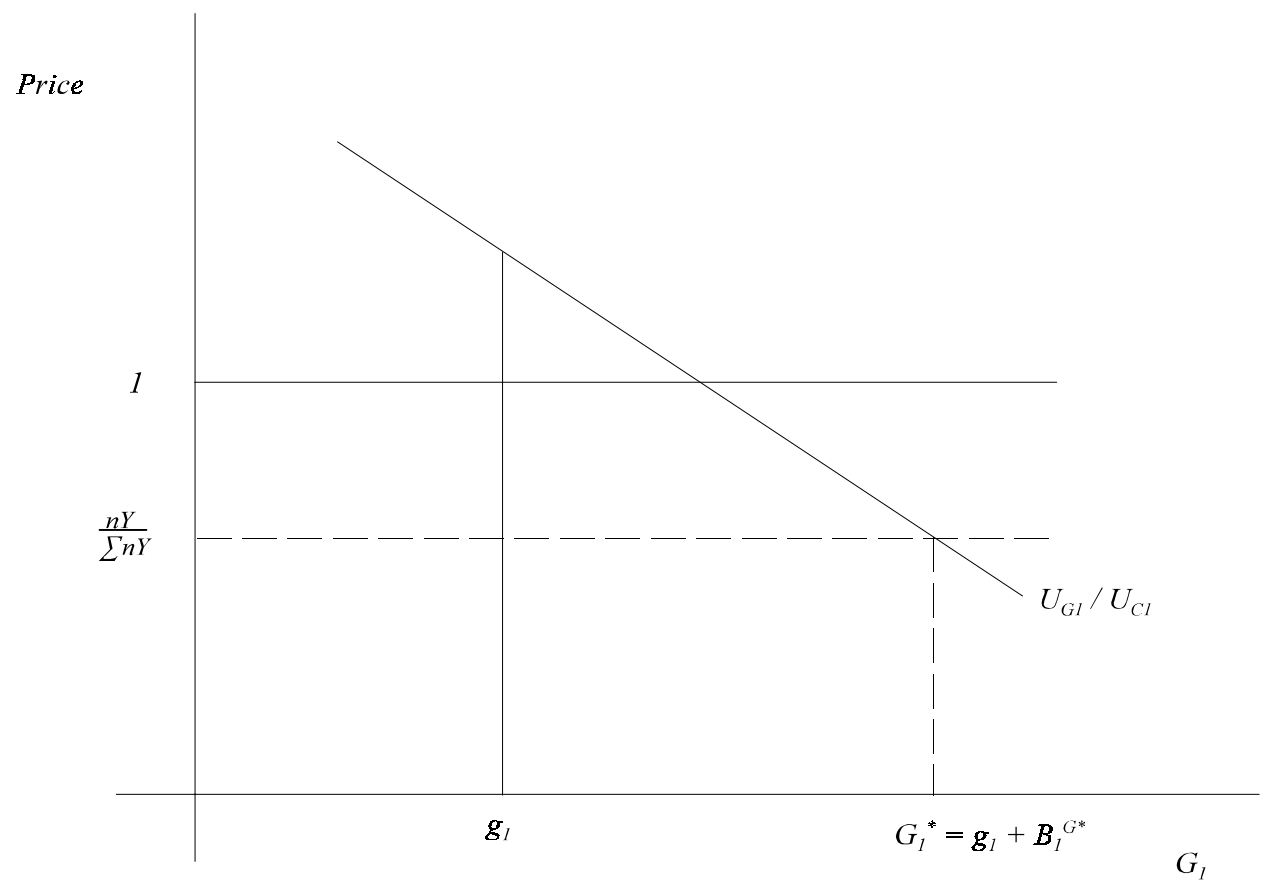


Table 1: Fiscal Responsibilities of Regions in Spain at Present, and 1995 Income Per Capita (pesetas)

\begin{tabular}{|c|c|c|c|c|c|}
\hline & \multirow{2}{*}{$\begin{array}{c}1995 \\
\text { Income } \\
\text { per Capita } \\
\end{array}$} & \multirow{2}{*}{$\begin{array}{l}\text { Relative to } \\
\text { Average for } \\
\text { Spain =100) } \\
\end{array}$} & \multirow{2}{*}{$\begin{array}{c}\text { Responsible for } \\
\text { Education } \\
\text { and Health } \\
\end{array}$} & \multicolumn{2}{|c|}{$\begin{array}{l}\text { Not Responsible for } \\
\text { Education and Health }\end{array}$} \\
\hline & & & & Uni-provincial & Multi-provincial \\
\hline Andalucía & $1,249,778$ & $(75)$ & $\mathrm{X}$ & & \\
\hline Aragón & $1,861,303$ & $(111)$ & & & $\mathrm{X}$ \\
\hline Asturias & $1,488,956$ & $(89)$ & & $\bar{X}$ & \\
\hline Baleares & $2,088,042$ & $(125)$ & & & $\mathrm{X}$ \\
\hline Canarias & $1,663,214$ & (99) & $\bar{X}$ & & \\
\hline Cantabria & $1,615,407$ & $(96)$ & & $\mathrm{X}$ & \\
\hline Castilla-León & $1,471,767$ & $(88)$ & & & $\mathrm{X}$ \\
\hline Castilla-La Mancha & $1,431,372$ & $(85)$ & & & $\bar{X}$ \\
\hline Cataluña & $2,064,897$ & (123) & $\mathrm{X}$ & & \\
\hline Extremadura & $1,165,115$ & $(70)$ & & & $\bar{X}$ \\
\hline Galicia & $1,331,317$ & $(79)$ & $\mathrm{X}$ & & \\
\hline Madrid & $2,032,177$ & $(121)$ & & $\mathrm{X}$ & \\
\hline Murcia & $1,528,922$ & (91) & & $\bar{X}$ & \\
\hline \begin{tabular}{|l} 
La Rioja \\
\end{tabular} & $2,274,291$ & $(136)$ & & $\bar{X}$ & \\
\hline Valenciana & $1,653,070$ & (99) & $\mathrm{X}$ & & \\
\hline
\end{tabular}

Table 2: Percentage of Total Revenues Attributed to Various Sources, Average Over 1984-1995 Period

\begin{tabular}{|l|c|c|c|c|}
\hline Region & Grants & Ceded Taxes & Borrowing & All other \\
\hline Andalucía & 84 & 9 & 6 & 1 \\
Aragón & 43 & 38 & 15 & 4 \\
Asturias & 49 & 30 & 14 & 7 \\
Baleares & 37 & 48 & 12 & 3 \\
Canarias & 57 & 34 & 6 & 3 \\
Cantabria & 54 & 29 & 15 & 2 \\
Castilla-León & 56 & 20 & 7 & 17 \\
Castilla-La Mancha & 78 & 14 & 5 & 2 \\
Cataluña & 67 & 16 & 15 & 2 \\
Extremadura & 70 & 15 & 8 & 7 \\
Galicia & 81 & 11 & 6 & 1 \\
Madrid & 50 & 30 & 15 & 4 \\
Murcia & 48 & 34 & 16 & 2 \\
Rioja & 52 & 34 & 11 & 3 \\
Valenciana & 74 & 20 & 6 & 1 \\
\hline Spain * & 71 & 17 & 10 & 2 \\
\hline
\end{tabular}

* Excluding Navarra and País Vasco 
Table 3: Debt Service As a Share of Revenues From Non-Capital Sources

\begin{tabular}{|l|ccc|}
\hline Region & 1984 & 1991 & 1995 \\
\hline Andalucía & 0.003 & 0.038 & 0.065 \\
Aragón & 0.000 & 0.051 & 0.143 \\
Asturias & 0.076 & 0.207 & 0.210 \\
Baleares & 0.052 & 0.114 & 0.098 \\
Canarias & 0.001 & 0.034 & 0.043 \\
Cantabria & 0.084 & 0.247 & 0.380 \\
Castilla-León & 0.000 & 0.043 & 0.067 \\
Castilla-La Mancha & 0.000 & 0.023 & 0.048 \\
Cataluña & 0.070 & 0.205 & 0.146 \\
Extremadura & 0.000 & 0.032 & 0.171 \\
Galicia & 0.004 & 0.026 & 0.084 \\
Madrid & 0.064 & 0.091 & 0.166 \\
Murcia & 0.109 & 0.222 & 0.214 \\
Rioja & 0.098 & 0.138 & 0.134 \\
Valenciana & 0.000 & 0.030 & 0.066 \\
\hline Spain * & 0.030 & 0.086 & 0.098 \\
\hline
\end{tabular}

* Excluding Navarra and País Vasco

Table 4: Income, Total Revenue, and Deficit Per Capita for Aggregate of Fifteen Regions*, Real (1986) Pesetas

\begin{tabular}{|c|c|c|c|}
\hline & Income Per Capita & Total Revenue Per Capita & Deficit Per Capita \\
\hline 1984 & 729,782 & 43,423 & -494 \\
1985 & 744,955 & 50,008 & 4,087 \\
1986 & 776,565 & 57,654 & 5,264 \\
1987 & 809,250 & 67,872 & 2,723 \\
1988 & 843,600 & 76,981 & 2,405 \\
1989 & 879,136 & 87,798 & 6,688 \\
1990 & 915,079 & 98,052 & 9,438 \\
1991 & 932,235 & 106,403 & 17,595 \\
1992 & 947,390 & 121,840 & 18,563 \\
1993 & 936,349 & 115,099 & 12,073 \\
1994 & 955,024 & 121,473 & 11,545 \\
1995 & 980,308 & 121,818 & 9,622 \\
\hline$\%$ annual & $3 \%$ & $10 \%$ & N.A. \\
increase & & & \\
\hline
\end{tabular}

* Excluding Navarra and País Vasco 
Table 5

Random Effects Results, Borrowing Per Capita

1984-1995

\begin{tabular}{|c|c|c|}
\hline & (1) & $(2)$ \\
\hline Income Per Capita * Low & $\begin{array}{c}4.72 \\
(0.77) \\
\end{array}$ & $\begin{array}{c}4.39 \\
(0.69) \\
\end{array}$ \\
\hline Income Per Capita * High & $\begin{array}{l}23.58 \\
(2.50) \\
\end{array}$ & $\begin{array}{l}33.06 \\
(3.64) \\
\end{array}$ \\
\hline Grants Per Capita & $\begin{array}{l}-0.007 \\
(0.12) \\
\end{array}$ & $\begin{array}{l}-0.02 \\
(0.39) \\
\end{array}$ \\
\hline Share Aggregate Income $*$ Low & $\begin{array}{l}-22.40 \\
(0.98) \\
\end{array}$ & \\
\hline Share Aggregate Income * High & $\begin{array}{l}65.93 \\
(2.15) \\
\end{array}$ & \\
\hline Share of Population * Low & & $\begin{array}{l}-34.40 \\
(1.21) \\
\end{array}$ \\
\hline Share of Population * High & & $\begin{array}{r}61.87 \\
(1.94) \\
\end{array}$ \\
\hline Health & $\begin{array}{c}2.29 \\
(0.58) \\
\end{array}$ & $\begin{array}{r}2.37 \\
(0.60) \\
\end{array}$ \\
\hline Education & $\begin{array}{l}-16.17 \\
(2.01) \\
\end{array}$ & $\begin{array}{l}-23.78 \\
(2.60) \\
\end{array}$ \\
\hline Uni-Provincial & $\begin{array}{c}4.31 \\
(2.12) \\
\end{array}$ & $\begin{array}{c}4.12 \\
(1.95) \\
\end{array}$ \\
\hline Constant & $\begin{array}{l}-6.97 \\
(1.26) \\
\end{array}$ & $\begin{array}{r}-5.59 \\
(0.96) \\
\end{array}$ \\
\hline $\begin{array}{l}\text { \# of observations } \\
\mathrm{R}^{2} \\
\text { Sum of squared residuals }\end{array}$ & $\begin{array}{r}180 \\
0.54 \\
9,168.2\end{array}$ & $\begin{array}{r}180 \\
0.54 \\
9,103.2\end{array}$ \\
\hline
\end{tabular}

Notes:

Health $=1.0$ for regions with responsibility for health, 0.0 otherwise.

Education $=1.0$ for regions with responsibility for education, 0.0 otherwise.

Uni-provincial $=1.0$ for Asturias, Cantabria, Madrid, Murcia and La Rioja, 0.0 otherwise.

High $=1.0$ for Andalucía, Canarias, Cataluña, Galicia and Valenciana, 0.0 otherwise.

Eleven yearly time dummies are included in each regression. t-statistics in parentheses. 